\title{
ANALISA KINERJA AUTOMATIC VOLTAGE REGULATOR DALAM DOMAIN WAKTU MENGGUNAKAN METODA ZIEGLER-NICHOLS DENGAN PENDEKATAN FIRST ORDER PLUS DEAD TIME
}

\author{
Heru Dibyo Laksono*, N. Riska, dan Novizon \\ Jurusan Teknik Elektro, Fakultas Teknik, Universitas Andalas \\ "Corresponding author, e-mail: heru_dl@eng.unand.ac.id
}

\begin{abstract}
Abstrak - Sistem tenaga listrik menghasilkan daya yang dapat di gunakan untuk berbagai keperluan. Penyaluran daya listrik ini erta hubungan nya dengan tegangan dan arus yang di hasilkan oleh pembangkit. Tegangan dapat berubah-ubah dengan berubahnya beban. Perubahan tegangan ini tidak diinginkan karena dapat mengakibatkan gangguan pada sistem tenaga. Untuk menjaga agar tegangan tetap stabil digunakan Automatic Voltage Regulator (AVR). AVR ini dilengkapi dengan sistim pengendalian untuk mendapatkan kestabilan tegangan sesuai dengan kriteria yang di tetapkan. Pada penelitian ini digunakan metoda Ziegler Nichols (Z-N) dengan pendekatan First Order Plus Dead Time (FOPDT) berdasarkan tanggapan frekuensi dan metoda fungsi alih sebagai metoda pengendali AVR dan AVR yang digunakan adalah AVR tipe arus searah.Pengendali yang memenuhi kriteria rancangan untuk pengendalian tanggapan peralihan tegangan sistem AVR tipe arus searah adalah pengendali Proporsional Integral Diferensial (PID). Pengendali Proporsional Integral Diferensial (PID) ini dirancang dengan menggunakan metoda Ziegler-Nichols dengan pendekatan First Order Plus Dead Time (FOPDT) berdasarkan metoda fungsi alih. Informasi hasil simulasi tanggapan peralihan sistem AVR tipe arus searah yang diperoleh dimana nilai kesalahan keadaan mantap sebesar 0.0000 , nilai waktu naik sebesar 0.6114 detik, nilai waktu puncak sebesar 1.4391 detik, nilai puncak sebesar 1.1492 detik, nilai lewatan maksimum sebesar $14.942 \%$ dan nilai waktu keadaan mantap sebesar 2.5562 detik. Untuk nilai parameter pengendali yang digunakan adalah $\mathrm{k}$ sebesar 13.2000, L sebesar 0.4283, T sebesar 1.0817, konstanta Proporsional $\left(\mathrm{K}_{\mathrm{p}}\right)$ sebesar 0.2296, konstanta waktu integral $\left(\mathrm{T}_{\mathrm{i}}\right)$ sebesar 0.8564 dan konstanta waktu diferensial $\left(\mathrm{T}_{\mathrm{d}}\right)$ sebesar 4.6667 .
\end{abstract}

Kata Kunci :Ziegler-Nichols, Fistt order plus dead time, Automatic voltage regulator, Analis peralihan,

\begin{abstract}
Electric power systems produce power that can be used for various purposes. The distribution of electrical power and its relationship to the voltage and current generated by the generator. Voltage can change with changes in load. The change of voltage is undesirable due to it can cause disturbances to the power system. A device called Automatic Voltage Regulator (AVR) is used to maintain the voltage stable. This AVR is equipped with a control system to get the voltage stability following the specified criteria. In this study, the Ziegler -Nichols (Z-N) method is used with the First Order Plus Dead Time (FOPDT) approach. FOPDT is used for AVR control based on frequency response and transfer function methods. AVR used is direct current type AVR. The design that fulfils the criteria for controlling the voltage transfer response of direct current type AVR systems is the Proportional Integral Differential (PID) controller. This PID is designed using the ZieglerNichols method with the FOPDT approach based on the transfer function method. Information on the simulation results of the direct current type of system switching AVR response is obtained where the steadystate error value is 0.0000 , the rise time value is 0.6114 seconds, the peak time value is 1.4391 seconds, the peak value is 1.1492 seconds, the maximum throughput is $14.942 \%$ and time to state steady reaches value at 2.5562 seconds. The values of parameter control are $\mathrm{k}$ of $13.2000, \mathrm{~L}$ of $0.4283, \mathrm{~T}$ of 1.0817 , Proportional constant (Kp) of 0.2296, integral time constant (Ti) of 0.8564 and differential time constant (Td) of 4.6667.
\end{abstract}

Keywords : Ziegler-Nichols, Fisrt order plus dead time, Automatic voltage regulator, Transient analysis

\section{Pendahuluan}

Sistem tenaga listrik adalah sistem tenaga yang terdiri dari generator, transmisi, dan beban. Generator merupakan suatu alat yang digunakan dalam pembangkitan tenaga listrik. Tenaga listrik ini disalurkan ke beban melalui saluran transmisi dan distribusi. Dalam proses penyaluran tenaga listrik ini, tegangan keluaran generator dapat berubah-ubah tergantung dari beban, sehingga bisa dikatakan bahwa perubahan beban sangat mempengaruhi tegangan keluaran generator. Tegangan keluaran generator ini harus tetap stabil, untuk itu dibutuhkan suatu alat yang mampu mengatur tegangan keluaran generator. Peralatan

Received date 2019-08-02, Revised date 2019-11-18, Accepted date 2019-11-19

https://doi.org/10.25077/v8n3.669.2019

This work is licensed under a Creative Commons Attribution-ShareAlike 4.0 International License. 
ini dikenal dengan Automatic Voltage Regulator (AVR). AVR disini berfungsi sebagai pengatur tegangan yang keluar dari generator, kemudian dilakukan pengaturan arus eksitasi secara otomatis.

Dalam pengaturan tegangan generator ini, Automatic Voltage Regulator (AVR) perlu memiliki sistem kendali yang baik agar setiap perubahan tegangan menuju keadaan stabil sesuai dengan kriteria pengendalian. Untuk itu perlu suatu sistem pengendalian Automatic Voltage Regulator (AVR) yang kokoh. Beberapa penelitian tentang pengendalian sistem Automatic Voltage Regulator (AVR) ini telah banyak dilakukan [1-6] tetapi sampai sekarang belum ada metoda yang memenuhi kriteria pengendalian yang sesuai dan belum memuaskan terutama untuk waktu naik, waktu puncak, waktu keadaan mantap yang mempuyai waktu yang besar, nilai puncak dan nilai lewatan maksimum yang melebihi batas yang telah ditetapkan.

Hasil dari penelitian ini diperolehnya informasi kesalahan dan peralihan serta nilai - nilai parameter pengendali yang digunakan untuk mengendalikan tanggapan peralihan tegangan AVR tipe arus searah berdasarkan domain waktu dan metoda fungsi alih. Pengendalian sistem Automatic Voltage Regulator (AVR) menggunakan metoda Ziegler-Nichols dengan pendekatan First Order Plus Dead Time (FOPDT), dimana pendekatan ini sudah terbukti mampu dalam mengendalikan sistem Automatic Voltage Regulator (AVR).

Berdasarkan beberapa penelitian sebelumnya terlihat bahwa analisa AVR menggunakan metoda Z-N dengan pendekatan FOPDT belum ada yang dilakukan, sehingga dengan menggunakan perangkat lunak Matlab dilakukanlah analisa AVR menggunakan metoda Z-N dengan pendekatan FOPDT, sehingga nantinya didapatkan informasi performansi berupa domain waktu dari sistem eksitasi generator.

\section{Tinjauan Pustaka}

Bagian ini membahas sistem AVR tipe arus, perancangan pengendali dengan metoda Ziegler Nichols dengan pendekatan FOPDT, analisa kesalahan dan analisa peralihan.

Untuk diagram blok untuk sistem AVR tipe arus searah diperlihatkan pada Gambar 1. Berikut [1] :

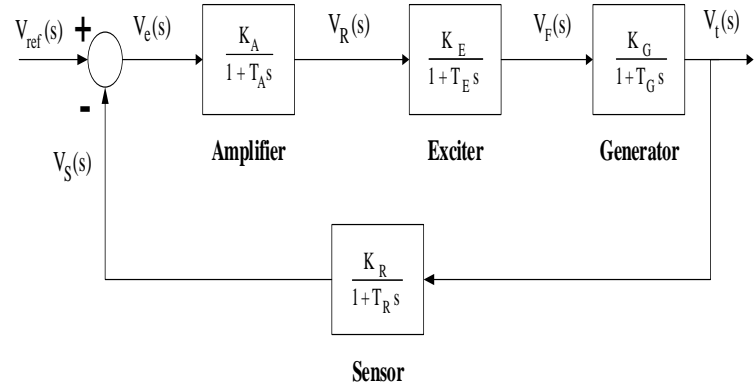

Gambar 1. Blok Diagram Sistem AVR dengan Tegangan Eksitasi

a. Model Generator

Emf yang dibangkitkan oleh generator merupakan fungsi dari proses magnetisasi sedangkan terminal tergantung dari beban. Model linier dari sebuah generator menggunakan sistem orde satu yang memiliki konstanta penguatan generator $\left(\mathrm{K}_{\mathrm{G}}\right)$ dan konstanta waktu generator $\left(\mathrm{T}_{\mathrm{G}}\right)$. Model generator ini dapat dinyatakan dalam bentuk persamaan (1) berikut [9-10]:

$$
\frac{\mathrm{V}_{\mathrm{t}}(\mathrm{s})}{\mathrm{V}_{\mathrm{F}}(\mathrm{s})}=\frac{\mathrm{K}_{\mathrm{G}}}{1+\mathrm{T}_{\mathrm{G}} \mathrm{s}}
$$

\section{b. Model Eksiter}

Eksitasi yang biasa digunakan untuk generator terdiri dari beberapa tipe mulai dari yang menggunakan generator DC dan untuk tipe modern menggunakan SCR sebagai penyearah untuk menghasilkan daya DC. Eksitasi modern yang baik digunakan adalah model linier yang bisa diambil untuk menghitung konstanta waktu yang besar dan mengabaikan saturasi atau non linier lainnya. Sehingga exciter dapat dimodelkan dengan sebuah sistem orde satu dengan konstanta penguatan eksiter $\left(\mathrm{K}_{\mathrm{E}}\right)$ dan konstanta waktu eksiter $\left(\mathrm{T}_{\mathrm{E}}\right)$. Fungsi alih sistem exciter dapat dilihat pada persamaan (2) berikut [9-10]:

$$
\frac{V_{F}(s)}{V_{R}(s)}=\frac{K_{E}}{1+T_{E} s}
$$

\section{c. Model Amplifier}

Penguatan pada sistem eksitasi ini berupa magnetik, putaran atau penguatan elektronik modern. Model amplifier ini dapat digambarkan dalam sistem orde satu dengan konstanta penguatan amplifier $\left(\mathrm{K}_{\mathrm{A}}\right)$ dan konstanta waktu amplifier $\left(\mathrm{T}_{\mathrm{A}}\right)$. Fungsi alih amplifier dapat dilihat pada persamaan (3) berikut [9-10]:

$$
\frac{V_{R}(s)}{V_{E}(s)}=\frac{K_{A}}{1+T_{A} s}
$$




\section{d. Model Sensor}

Sensor terdiri dari transformator tegangan (PT) yang berfungsi menurunkan tegangan tinggi ke tegangan rendah dan sebuah penyearah. Sensor ini secara sederhana dapat dimodelkan dalam sistem orde satu dengan konstanta penguatan sensor $\left(\mathrm{K}_{\mathrm{R}}\right)$ dan konstanta waktu sensor $\left(T_{R}\right)$. Fungsi alih amplifier dapat dilihat pada persamaan (4) berikut [9-10]:

$$
\frac{\mathrm{V}_{\mathrm{S}}(\mathrm{s})}{\mathrm{V}_{\mathrm{t}}(\mathrm{s})}=\frac{\mathrm{K}_{\mathrm{R}}}{1+\mathrm{T}_{\mathrm{R}} \mathrm{s}}
$$

Metoda penyetelan Ziegler-Nichols merupakan metoda heuristik dari tuning kontroller PID. Hal ini dikembangkan oleh John G. Ziegler dan Nathaniel B. Nichols. Metoda Z-N dilakukan dengan mengatur Integral (I) dan Derivatif (D) menjadi nol. Gain Proporsional (P), Kp kemudian dinaikkan hingga mencapai gain tertunggi $\mathrm{Ku}$, dimana output dari loop kontrol memiliki osilasi yang stabil dan konsisten [7]. Gain tertinggi $(\mathrm{Ku})$ dan periode osilasi (Tu) digunakan untuk mengatur P, I, dan D tergantung pada jenis pengendali yang digunakan. Dalam penelitian ini metode Z-N menggunakan pendekatan FOPDT dimana FOPDT adalah model proses pengaturan sendiri (self regulating) yang bersifat stabil untuk tuning parameter kontrol P. I dan D [7]. Proses ini dapat berupa model yang dikenal dengan First Order Plus Dead Time (FOPDT) dengan ciri-ciri berikut

a. Keterlambatan Transportasi (L)

Keterlambatan transportasi (L) adalah waktu yang hitung sejak terjadinya perubahan state pada input sampai variable proses output yang dikontrol mulai menanggapi perubahan input.

b. Konstanta Waktu Proses (T)

Konstanta waktu proses ( $\mathrm{T}$ ) adalah waktu yang diperlukan sehingga nilai output mencapai kurang lebih $63 \%$ dari keadaan stedy akhir setelah waktu tunda.

c. Gain Statis Proses (K)

Gain statis proses adalah perbandingan perubahan output terhadap perubahan input dalam keadaan stedynya. Gain statis bias bersifat positif maupun negative tergantung jenis kontrol yang digunakan.

Ketiga parameter yang menggambarkan dinamika proses tersebut, secara praktis dapat diperoleh atau diidentifikasi melalui eksperimen sederhana pengujian sinyal tangga secara lingkar terbuka pada mode kendali manual. Adapun jenis pengendali yang digunakan adalah pengendali Proporsional (P), Proporsional Integral (PI) dan
Proporsional Integral Diferensial (PID). Ketiga pengendali tersebut dinyatakan dlam bentuk persamaan (5) s/d (7) berikut [7]:

$$
\begin{aligned}
& \mathrm{G}_{\mathrm{c}}(\mathrm{s})=\mathrm{K}_{\mathrm{p}} \\
& \mathrm{G}_{\mathrm{c}}(\mathrm{s})=\mathrm{K}_{\mathrm{p}}\left(1+\frac{1}{\mathrm{~T}_{\mathrm{i}} \mathrm{s}}\right) \\
& \mathrm{G}_{\mathrm{c}}(\mathrm{s})=\mathrm{K}_{\mathrm{p}}\left(1+\frac{1}{\mathrm{~T}_{\mathrm{i}} \mathrm{s}}+\mathrm{T}_{\mathrm{d}} \mathrm{s}\right)
\end{aligned}
$$

dimana

$$
\begin{array}{ll}
\mathrm{K}_{\mathrm{p}} & : \text { Konstanta proporsional } \\
\mathrm{T}_{\mathrm{i}} & : \text { Waktu integral } \\
\mathrm{T}_{\mathrm{d}} & : \text { Waktu diferensial }
\end{array}
$$

Perhitungan konstanta proporsional $\left(\mathrm{K}_{\mathrm{p}}\right)$, konstanta waktu integral $\left(\mathrm{T}_{\mathrm{i}}\right)$ dan konstanta waktu diferensial $\left(\mathrm{T}_{\mathrm{d}}\right)$ dilakukan berdasarkan tanggapan frekuensi dan fungsi alih ini diperlihatkan pada Tabel 1. berikut [7]:

Tabel 1. Formula Ziegler - Nichols Untuk Perancangan Pengendali

\begin{tabular}{|l|c|c|c|}
\hline \multirow{2}{*}{ Tipe Pengendali } & \multicolumn{3}{|c|}{ Berdasarkan Tanggapan } \\
\cline { 2 - 4 } & $\mathrm{K}_{\mathrm{p}}$ & $\mathrm{T}_{\mathrm{i}}$ & $\mathrm{T}_{\mathrm{d}}$ \\
\hline Proporsional (P) & $\frac{1}{\mathrm{a}}$ & & \\
\hline $\begin{array}{l}\text { Proporsional - Integral } \\
\text { (PI) }\end{array}$ & $\frac{0.90}{\mathrm{a}}$ & $3.33 \mathrm{~L}$ & \\
\hline $\begin{array}{l}\text { Proporsional - Integral - } \\
\text { Diferensial (PID) }\end{array}$ & $\frac{1.20}{\mathrm{a}}$ & $2 \mathrm{~L}$ & $\frac{\mathrm{L}}{2}$ \\
\hline
\end{tabular}

Untuk analisa kesalahan sistem AVR tipe arus searah dilakukan tanpa dan dengan pengendali. Adapun parameter yang diamati adalah nilai kesalahan keadaan mantap. Nilai kesalahan keadaan mantap ini diperoleh dari fungsi alih lingkar terbuka tanpa dan dengan pengendali [7]. Analisa peralihan sistem AVR tipe arus searah diperoleh dari fungsi alih lingkar tertutup tanpa dan dengan pengendali. Parameter - parameter yang diamati meliputi waktu naik, waktu puncak, waktu keadaan mantap, nilai puncak dan nilai lewatan maksimum [7].

\section{Metodologi}

Bagian ini menjelaskan langkah - langkah yang dilakukan dalam penelitian, diagram blok sistem AVR dengan pengendali, parameter sistem AVR dan kriteria perancangan pengendali sistem AVR. 


\section{a. Langkah-langkah Penelitian}

Adapun langkah dalam penelitian ini diawali dengan studi literatur. Pada studi literatur ini kegiatan yang dilakukan adalah mengumpulkan literatur yang berkaitan dengan pengendalian sistem AVR dengan metoda Ziegler - Nichols dengan pendekatan FOPDT. Tipe AVR yang digunakan adalah AVR tipe arus searah. Selanjutnya dilakukan pemodelan matematis sistem AVR. Hasil dari pemodelan ini diperolehnya fungsi alih lingkar terbuka dan fungsi alih lingkar tertutup dari sistem AVR. Dengan keluaran adalah tegangan $\left(\mathrm{V}_{\mathrm{t}}\right)$ dan masukan adalah tegangan referensi $\left(\mathrm{V}_{\text {ref }}\right)$. Dengan menggunakan fungsi alih lingkar terbuka dan fungsi alih lingkar tertutup ini dilakukan analisa kesalahan dan analisa peralihan sistem AVR. Untuk analisa kesalahan, parameter yang diamati adalah nilai kesalahan keadaan mantap. Analisa kesalahan ini dilakukan dengan menggunakan fungsi alih lingkar terbuka. Untuk analisa peralihan, parameter yang diamati waktu naik, waktu puncak, waktu keadaan mantap, nilai puncak dan nilai keadaan mantap. Analisa peralihan ini dilakukan dengan menggunakan fungsi alih lingkar tertutup. Berdasarkan kedua hasil analisa ini kemudian ditentukan kriteria perancangan pengendali. Pengendali dirancang dengan menggunakan metoda Ziegler-Nichols pendekatan FOPDT berdasarkan tanggapan frekuensi dan berdasarkan tanggapan fungsi alih. Jenis pengendali yang dirancang terdiri dari pengendali Proporsional $(\mathrm{P}), \quad$ pengendali Proporsional Integral (PI) dan pengendali Proporsional Integral Diferensial (PID).

Hasil dari perancangan pengendali diperoleh fungsi alih dari pengendali Proporsional (P), pengendali Proporsional Integral (PI) dan pengendali Proporsional Integral Diferensial (PID). Selanjutnya fungsi alih masing - masing pengendali digabung dengan fungsi alih lingkar terbuka dan fungsi alih lingkar tertutup dari sistem AVR. Selanjutnya dilakukan kembali analisa kesalahan dan analisa peralihan untuk sistem AVR dengan masing - masing pengendali. Hasil dari analisa nantinya akan diperoleh informasi pengendali yang memenuhi kriteria perancangan untuk pengendalian sistem AVR.

\section{b. Diagram Blok Sistem AVR}

Adapun model diagram blok dari sistem AVR tipe arus searah dengan pengendali diperlihatkan pada Gambar 2.

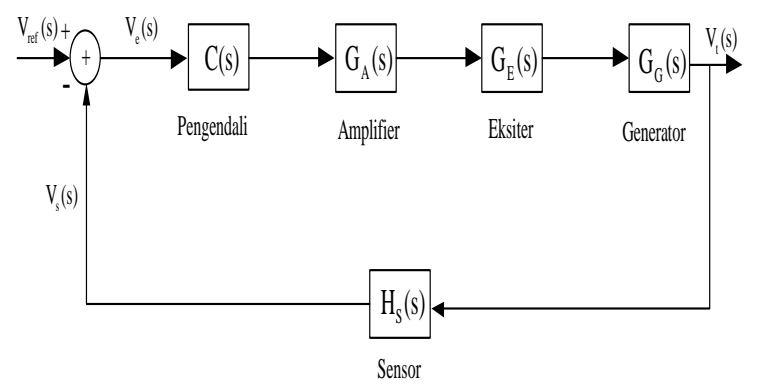

Gambar 2. Blok Diagram Sistem AVR Tipe Arus Searah

Nilai parameter sistem AVR yang digunakan diperlihatkan pada Tabel 2.

Tabel 2. Nilai Parameter Sistem AVR

\begin{tabular}{|c|l|c|}
\hline No. & \multicolumn{1}{|c|}{ Parameter } & Nilai \\
\hline 1 & Konstanta Penguatan Amplifier $\left(\mathrm{K}_{\mathrm{a}}\right)$ & 15.0000 \\
\hline 2 & Konstanta Waktu Amplifier $\left(\mathrm{T}_{\mathrm{a}}\right)$ & $\begin{array}{c}0.1000 \\
\text { detik }\end{array}$ \\
\hline 3 & Konstanta Penguatan Exciter $\left(\mathrm{K}_{\mathrm{E}}\right)$ & 1.0000 \\
\hline 4 & Konstanta Waktu Eksiter $\left(\mathrm{T}_{\mathrm{E}}\right)$ & $\begin{array}{c}0.4000 \\
\text { detik }\end{array}$ \\
\hline 5 & Konstanta Penguatan Genertor $\left(\mathrm{K}_{\mathrm{G}}\right)$ & 0.8000 \\
\hline 6 & Konstanta Waktu Generator $\left(\mathrm{T}_{\mathrm{G}}\right)$ & 1.000 detik \\
\hline 7 & Konstanta Penguatan Sensor $\left(\mathrm{K}_{\mathrm{s}}\right)$ & 1.1000 \\
\hline 8 & Konstanta Waktu Eksiter $\left(\mathrm{T}_{\mathrm{s}}\right)$ & $\begin{array}{c}0.0100 \\
\text { detik }\end{array}$ \\
\hline
\end{tabular}

Untuk kriteria perancangan pengendali sistem AVR diperlihatkan pada Tabel 3.

Tabel 3. Kriteria Pengendali AVR

\begin{tabular}{|c|l|c|}
\hline No. & \multicolumn{1}{|c|}{ Parameter } & Nilai \\
\hline 1 & Kesalahan Keadaan Mantap & $<0.0500$ \\
\hline 2 & Waktu Naik & $<0.7500$ detik \\
\hline 3 & Waktu Puncak & $<1.5000$ detik \\
\hline 4 & Waktu Keadaan Mantap & $<3.0000$ detik \\
\hline 5 & Nilai Puncak & $<1.5000$ \\
\hline 6 & Lewatan Maksimum & $<20.0000 \%$ \\
\hline
\end{tabular}

\section{Hasil dan Pembahasan}

Pada bagian ini diamati perilaku tanggapan peralihan tegangan sistem AVR tipe arus searah tanpa dan dengan pengendali. Perancangan pengendali dan analisa sistem kendali AVR tipe arus searah dilakukan menggunakan metoda Ziegler-Nichols dengan pendekatan First Order 
Plus Dead Time (FOPDT) berdasarkan tanggapan frekuensi dan metoda fungsi alih. Perancangan dan analisa dilakukan dengan simulasi menggunakan perangkat lunak Matlab. Pengendali yang dirancang terdiri dari pengendali Proporsional $(\mathrm{P})$, pengendali Proporsional Integral (PI) dan Pengendali Proporsional Integral diferensial (PID). Analisa yang dilakukan terdiri dari analisa kesalahan dan analisa peralihan.

Hasil perancangan dan analisa sistem kendali AVR tipe arus searah diperoleh menggunakan metoda Ziegler-Nichols dengan pendekatan First Order Plus Dead Time (FOPDT) berdasarkan tanggapan frekuensi dimana untuk pengendali Proporsional (P) diperoleh nilai parameter pengendali yaitu $\mathrm{k}=13.2000, \mathrm{~L}=0.2826, \mathrm{~T}=$ 2.9456 dan konstanta Proporsional $\left(\mathrm{K}_{\mathrm{p}}\right)=0.7897$. Dengan substitusi nilai pengendali Proporsional $\left(\mathrm{K}_{\mathrm{p}}\right)$ ke blok pengendali $\mathrm{C}(\mathrm{s})$ pada diagram blok pada Gambar 2 dan disimulasikan dengan menggunakan perangkat lunak Matlab serta diperoleh hasil simulasi dari tanggapan peralihan tegangan sistem AVR tipe arus searah yang diperlihatkan pada Tabel 4.

Tabel 4. Hasil simulasi Tanpa dan Dengan Pengendali Proporsional (P)

\begin{tabular}{|l|c|c|}
\hline \multicolumn{1}{|c|}{ Kriteria } & $\begin{array}{c}\text { Tanpa } \\
\text { Pengendali }\end{array}$ & $\begin{array}{c}\text { Dengan } \\
\text { Pengendali }\end{array}$ \\
\hline $\begin{array}{l}\text { Kesalahan Keadaan } \\
\text { Mantap }\end{array}$ & 0.0704 & 0.0875 \\
\hline Waktu Naik & 0.2252 detik & 0.2555 detik \\
\hline Waktu Puncak & 0.6798 detik & 0.7479 detik \\
\hline Nilai Puncak & 1.5120 & 1.5288 \\
\hline Lewatan Maksimum & $78.9201 \%$ & $67.5409 \%$ \\
\hline Waktu Keadaan Mantap & 14.0265 detik & 7.5349 detik \\
\hline
\end{tabular}

Tampilan tanggapan peralihan tegangan sistem AVR tipe arus searah tanpa dan dengan pengendali Proporsional (P) terhadap masukan undak satuan diperlihatkan pada Gambar 3.

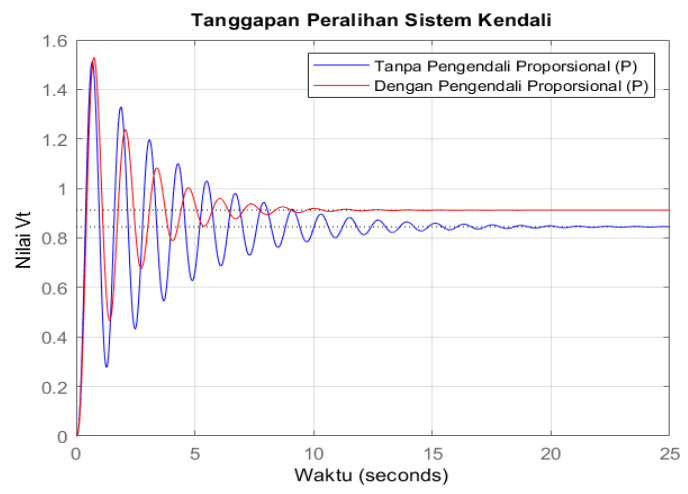

Gambar 3. Grafik Tanggapan Peralihan Tanpa dan Dengan Pengendali Proporsional (P)

Untuk pengendali Proporsional Integral (PI) diperoleh nilai parameter pengendali yaitu $\mathrm{k}=$ 10.0000, $\mathrm{L}=0.2826, \mathrm{~T}=2.9456$, konstanta Proporsional $\left(\mathrm{K}_{\mathrm{p}}\right)=0.7108$ dan konstanta waktu integral $\left(\mathrm{T}_{\mathrm{i}}\right)=1.0454$. Dengan substitusi nilai konstanta Proporsional $\left(\mathrm{K}_{\mathrm{p}}\right)$ dan konstanta waktu integral $\left(\mathrm{T}_{\mathrm{i}}\right)$ ke blok pengendali $\mathrm{C}(\mathrm{s})$ pada diagram blok pada Gambar 2 dan disimulasikan dengan menggunakan perangkat lunak Matlab serta diperoleh hasil simulasi dari tanggapan peralihan tegangan sistem AVR tipe arus searah yang diperlihatkan pada Tabel 5.

Tabel 5. Hasil simulasi Tanpa dan Dengan Pengendali Proporsional Integral (PI)

\begin{tabular}{|l|c|c|}
\hline \multicolumn{1}{|c|}{ Kriteria } & $\begin{array}{c}\text { Tanpa } \\
\text { Pengendali }\end{array}$ & $\begin{array}{c}\text { Dengan } \\
\text { Pengendali }\end{array}$ \\
\hline $\begin{array}{l}\text { Kesalahan Keadaan } \\
\text { Mantap }\end{array}$ & 0.0704 & 0.0000 \\
\hline Waktu Naik & 0.2252 detik & 0.2597 detik \\
\hline Waktu Puncak & 0.6798 detik & 0.8057 detik \\
\hline Nilai Puncak & 1.5120 & 1.8707 \\
\hline Lewatan Maksimum & $78.9201 \%$ & $87.0739 \%$ \\
\hline Waktu Keadaan Mantap & 14.0265 detik & $\begin{array}{c}33.8969 \\
\text { detik }\end{array}$ \\
\hline
\end{tabular}

Tampilan tanggapan peralihan tegangan sistem AVR tipe arus searah tanpa dan dengan pengendali Proporsional Integral (PI) terhadap masukan undak satuan diperlihatkan pada Gambar 4. 


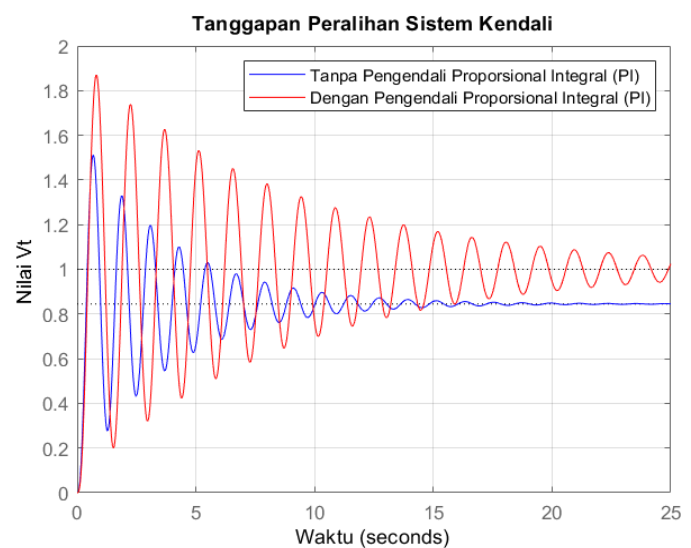

Gambar 4. Grafik Tanggapan Peralihan Tanpa dan Dengan Pengendali Proporsional Integral (PI)

Untuk pengendali Proporsional Integral Diferensial (PID) diperoleh nilai parameter pengendali yaitu $\mathrm{k}=13.2000, \mathrm{~L}=0.2826, \mathrm{~T}=$ 2.9456, konstanta Proporsional $\left(\mathrm{K}_{\mathrm{p}}\right)=0.9477$, konstanta waktu integral $\left(\mathrm{T}_{\mathrm{i}}\right)=0.5651$ dan konsntanta waktu diferensial $\left(\mathrm{T}_{\mathrm{d}}\right)=0.1413$. Dengan substitusi nilai konstanta Proporsional $\left(\mathrm{K}_{\mathrm{p}}\right)$, konstanta waktu integral $\left(\mathrm{T}_{\mathrm{i}}\right)$ dan konsntanta waktu diferensial $\left(\mathrm{T}_{\mathrm{d}}\right)$ ke blok pengendali $\mathrm{C}(\mathrm{s})$ pada diagram blok pada Gambar 2 dan disimulasikan dengan menggunakan perangkat lunak Matlab serta diperoleh hasil simulasi dari tanggapan peralihan tegangan sistem AVR tipe arus searah yang diperlihatkan pada Tabel 6 .

Tabel 6. Hasil simulasi Tanpa dan Dengan

Pengendali Proporsional Integral Diferensial (PID)

\begin{tabular}{|l|c|c|}
\hline \multicolumn{1}{|c|}{ Kriteria } & $\begin{array}{c}\text { Tanpa } \\
\text { Pengendali }\end{array}$ & $\begin{array}{c}\text { Dengan } \\
\text { Pengendali }\end{array}$ \\
\hline $\begin{array}{l}\text { Kesalahan Keadaan } \\
\text { Mantap }\end{array}$ & 0.0704 & 0.0000 \\
\hline Waktu Naik & 0.2252 detik & 0.2079 detik \\
\hline Waktu Puncak & 0.6798 detik & 0.5797 detik \\
\hline Nilai Puncak & 1.5120 & 1.5054 \\
\hline Lewatan Maksimum & $78.9201 \%$ & $50.5396 \%$ \\
\hline Waktu Keadaan Mantap & 14.0265 detik & 2.6272 detik \\
\hline
\end{tabular}

Tampilan tanggapan peralihan tegangan sistem AVR tipe arus searah tanpa dan dengan pengendali Proporsional Integral Diferensial (PID) terhadap masukan undak satuan diperlihatkan pada Gambar 5.

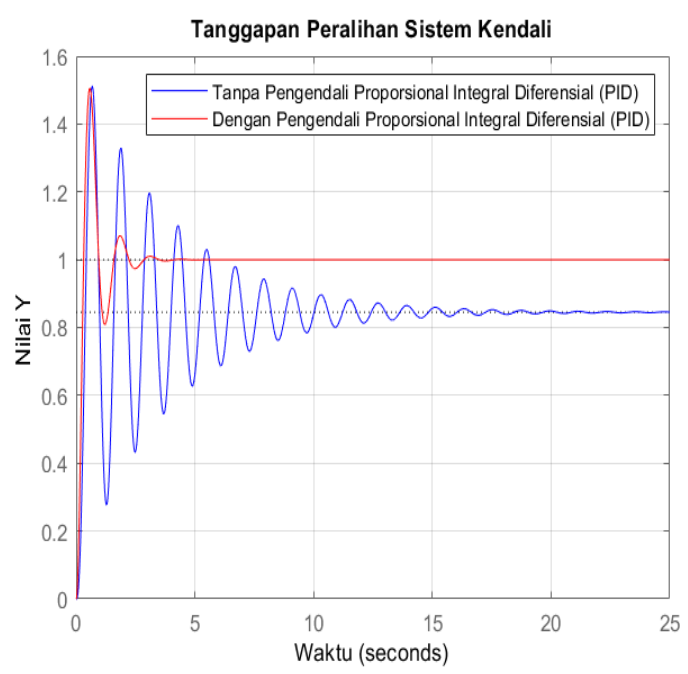

Gambar 5. Grafik Tanggapan Peralihan Tanpa dan Dengan Pengendali Proporsional Integral Diferensial (PID)

Hasil simulasi memperlihatkan bahwa dengan pengendali Proporsional (P), Proporsional Integral (PI) dan Proporsional Integral Diferensial (PID), tanggapan peralihan tegangan sistem AVR tipe arus searah belum memenuhi kriteria perancangan terutama untuk nilai kesalahan, nilai puncak, nilai lewatan maksimum dan waktu keadaan mantap. Untuk nilai kesalahan keadaan mantap masih besar dari 0.0500 terutama untuk pengendali Proporsional (P) sedangkan untuk pengendali Proporsional Integral (PI) dan pengendali Proporsional Integral Diferensial (PID), nilai kesalahan keadaan mantapnya sudah memenuhi kriteria perancangan. Untuk nilai puncak dan lewatan maksimum, tidak ada satupun pengendali yang memenuhi kriteria perancangan dimana untuk nilai puncak harus lebih kecil dari 1.5000 sedangkan lewatan maksimum harus lebih dari $20.0000 \%$. Untuk waktu keadaan mantap, hanya pengendali Proporsional Integral Diferensial (PID) saja yang memenuhi kriteria perancangan dengan nilai 2.6272 detik sedangkan kriteria perancangan untuk waktu keadaan mantap harus lebih kecil dari 3.0000 detik.

Hasil perancangan dan analisa sistem kendali AVR tipe arus searah diperoleh menggunakan metoda Ziegler-Nichols dengan pendekatan First Order Plus Dead Time (FOPDT) berdasarkan metoda fungsi alih dimana untuk pengendali Proporsional (P) diperoleh nilai parameter pengendali yaitu $\mathrm{k}=13.2000, \mathrm{~L}=0.4283, \mathrm{~T}=$ 1.0817 dan konstanta Proporsional $\left(\mathrm{K}_{\mathrm{p}}\right)=0.1913$. Dengan substitusi nilai pengendali Proporsional 
$\left(\mathrm{K}_{\mathrm{p}}\right)$ ke blok pengendali $\mathrm{C}(\mathrm{s})$ pada diagram blok pada Gambar 2 dan disimulasikan dengan menggunakan perangkat lunak Matlab serta diperoleh hasil simulasi dari tanggapan peralihan tegangan sistem AVR tipe arus searah yang diperlihatkan pada Tabel 7.

Tabel 7. Hasil simulasi Tanpa dan Dengan Pengendali Proporsional (P)

\begin{tabular}{|l|c|c|}
\hline \multicolumn{1}{|c|}{ Kriteria } & $\begin{array}{c}\text { Tanpa } \\
\text { Pengendali }\end{array}$ & $\begin{array}{c}\text { Dengan } \\
\text { Pengendali }\end{array}$ \\
\hline $\begin{array}{l}\text { Kesalahan Keadaan } \\
\text { Mantap }\end{array}$ & 0.0704 & 0.2836 \\
\hline Waktu Naik & 0.2252 detik & 0.5794 detik \\
\hline Waktu Puncak & 0.6798 detik & 1.3566 detik \\
\hline Nilai Puncak & 1.5120 & 0.8487 \\
\hline Lewatan Maksimum & $78.9201 \%$ & $18.4772 \%$ \\
\hline Waktu Keadaan Mantap & 14.0265 detik & 3.0109 detik \\
\hline
\end{tabular}

Tampilan tanggapan peralihan tegangan sistem AVR tipe arus searah tanpa dan dengan pengendali Proporsional $(\mathrm{P})$ terhadap masukan undak satuan diperlihatkan pada Gambar 6.

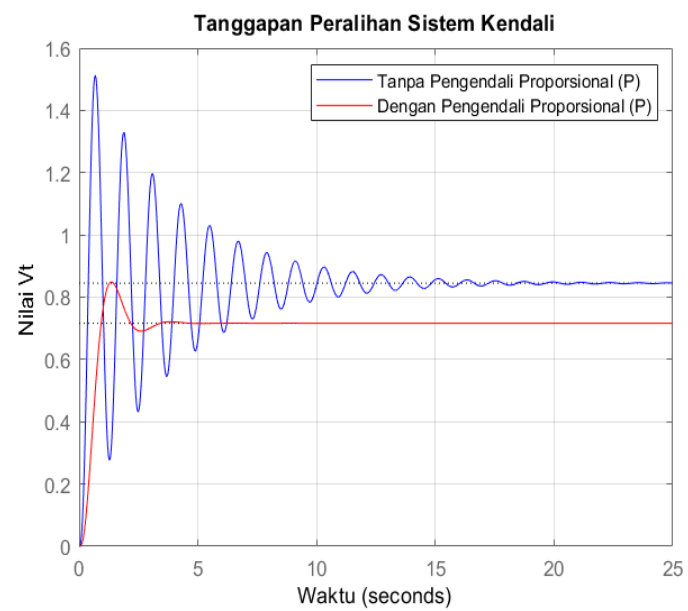

Gambar 6. Grafik Tanggapan Peralihan Tanpa dan Dengan Pengendali Proporsional (P)

Untuk pengendali Proporsional Integral (PI) diperoleh nilai parameter pengendali yaitu $\mathrm{k}=$ 13.2000, $\mathrm{L}=0.4283, \mathrm{~T}=1.017$, konstanta Proporsional $\left(\mathrm{K}_{\mathrm{p}}\right)=0.1722$ dan konstanta waktu integral $\left(\mathrm{T}_{\mathrm{i}}\right)=1.4267$. Dengan substitusi nilai konstanta Proporsional $\left(\mathrm{K}_{\mathrm{p}}\right)$ dan konstanta waktu integral $\left(\mathrm{T}_{\mathrm{i}}\right)$ ke blok pengendali $\mathrm{C}(\mathrm{s})$ pada diagram blok pada Gambar 2 dan disimulasikan dengan menggunakan perangkat lunak Matlab serta diperoleh hasil simulasi dari tanggapan peralihan tegangan sistem AVR tipe arus searah yang diperlihatkan pada Tabel 8 .

Tabel 8. Hasil simulasi Tanpa dan Dengan Pengendali Proporsional Integral (PI)

\begin{tabular}{|l|c|c|}
\hline \multicolumn{1}{|c|}{ Kriteria } & $\begin{array}{c}\text { Tanpa } \\
\text { Pengendali }\end{array}$ & $\begin{array}{c}\text { Dengan } \\
\text { Pengendali }\end{array}$ \\
\hline $\begin{array}{l}\text { Kesalahan Keadaan } \\
\text { Mantap }\end{array}$ & 0.0704 & 0.0000 \\
\hline Waktu Naik & 0.2252 detik & 0.7205 detik \\
\hline Waktu Puncak & 0.6798 detik & 1.6089 detik \\
\hline Nilai Puncak & 1.5120 & 1.1352 \\
\hline Lewatan Maksimum & $78.9201 \%$ & $13.5245 \%$ \\
\hline Waktu Keadaan Mantap & 14.0265 detik & 3.7537 detik \\
\hline
\end{tabular}

Tampilan tanggapan peralihan tegangan sistem AVR tipe arus searah tanpa dan dengan pengendali Proporsional Integral (PI) terhadap masukan undak satuan diperlihatkan pada Gambar 7.

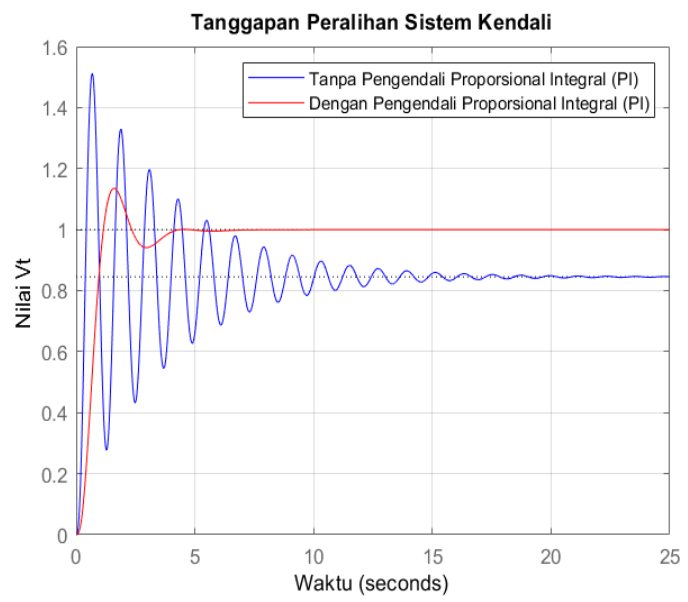

Gambar 7. Grafik Tanggapan Peralihan Tanpa dan Dengan Pengendali Proporsional Integral (PI)

Untuk pengendali Proporsional Integral Diferensial (PID) diperoleh nilai parameter pengendali yaitu $\mathrm{k}=13.2000, \mathrm{~L}=0.4283, \mathrm{~T}=$ 1.0817, konstanta Proporsional $\left(\mathrm{K}_{\mathrm{p}}\right)=0.2296$, konstanta waktu integral $\left(\mathrm{T}_{\mathrm{i}}\right)=0.8564$ dan konsntanta waktu diferensial $\left(\mathrm{T}_{\mathrm{d}}\right)=4.6667$. Dengan substitusi nilai konstanta Proporsional $\left(\mathrm{K}_{\mathrm{p}}\right)$, konstanta waktu integral $\left(\mathrm{T}_{\mathrm{i}}\right)$ dan konsntanta waktu diferensial $\left(\mathrm{T}_{\mathrm{d}}\right)$ ke blok pengendali $\mathrm{C}(\mathrm{s})$ pada diagram blok pada Gambar 2 dan disimulasikan dengan menggunakan perangkat lunak Matlab serta diperoleh hasil simulasi dari tanggapan peralihan tegangan sistem AVR tipe arus searah yang diperlihatkan pada Tabel 9. 
Tabel 9. Hasil simulasi Tanpa dan Dengan Pengendali Proporsional Integral Diferensial (PID)

\begin{tabular}{|l|c|c|}
\hline \multicolumn{1}{|c|}{ Kriteria } & $\begin{array}{c}\text { Tanpa } \\
\text { Pengendali }\end{array}$ & $\begin{array}{c}\text { Dengan } \\
\text { Pengendali }\end{array}$ \\
\hline $\begin{array}{l}\text { Kesalahan Keadaan } \\
\text { Mantap }\end{array}$ & 0.0704 & 0.0000 \\
\hline Waktu Naik & 0.2252 detik & 0.6114 detik \\
\hline Waktu Puncak & 0.6798 detik & 1.4391 detik \\
\hline Nilai Puncak & 1.5120 & 1.1494 \\
\hline Lewatan Maksimum & $78.9201 \%$ & $14.9427 \%$ \\
\hline Waktu Keadaan Mantap & 14.0265 detik & 2.5562 detik \\
\hline
\end{tabular}

Tampilan tanggapan peralihan tegangan sistem AVR tipe arus searah tanpa dan dengan pengendali Proporsional Integral Diferensial (PID) terhadap masukan undak satuan diperlihatkan pada Gambar 8.

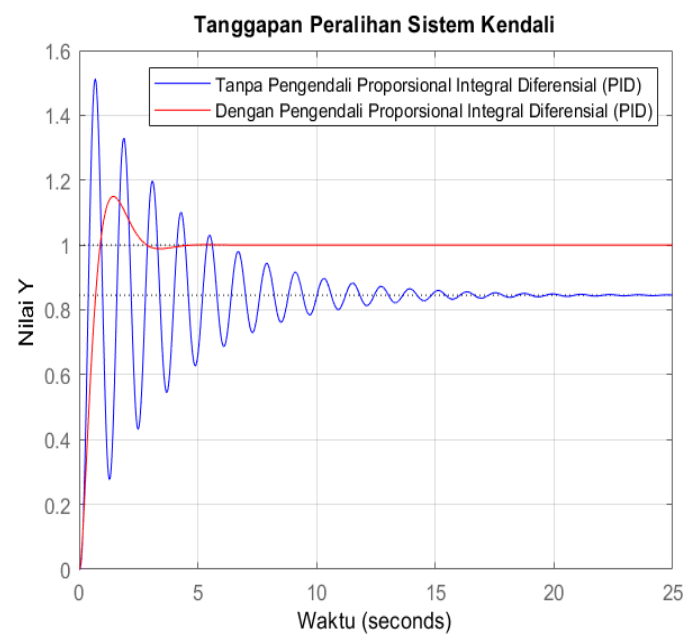

Gambar 8. Grafik Tanggapan Peralihan Tanpa dan Dengan Pengendali Proporsional Integral Diferensial (PID)

Hasil simulasi memperlihatkan bahwa nilai kesalahan keadaan mantap untuk pengendali Proporsional (P) belum memenuhi kriteria perancangan dimana besarnya nilai kesalahan keadaan mantap sebesar 0.2836 sedangkan untuk pengendali Proporsional Integral (PI) dan pengendali Proporsional Integral Diferensial (PID), nilai kesalahan keadaan mantapnya sudah memenuhi kriteria perancangan dimana nilai kesalahan keadaan mantap untuk pengendali Proporsional Integral (PI) dan Proporsional Integral Diferensial (PID) sebesar 0.0000 sedangkan kriteria perancangan untuk nilai kesalahan keadaan matap ini kecil dari 0.0500
Untuk waktu naik, tanggapan peralihan tegangan sistem AVR tipe arus searah untuk ketiga pengendali sudah memenuhi kriteria perancangan dimana nilai waktu naik yang diinginkan kecil dari 0.7500 detik. Untuk pengendali Proporsional (P), tanggapan peralihan tegangan sistem AVR tipe arus searah mempuyai waktu naik sebesar 0.5794 detik, untuk pengendali Proporsional Integral (PI) mempuyai waktu naik sebesar 0.7205 detik dan untuk pengendali Proporsional Integral Diferensial (PID) mempuyai waktu naik sebesar 0.6114 detik.

Untuk waktu puncak, tanggapan peralihan tegangan sistem AVR tipe arus searah dengan pengendali Proporsional (P) dan pengendali Proporsional Integral Diferensial (PID) saja yang memenuhi kriteria perancangan dengan nilai masing - masing sebesar 1.3566 detik dan 1.4391 detik sedangkan untuk pengendali Proporsional Integral (PID) belum memenuhi kriteria perancangan dengan nilai 1.6089 detik sedangkan kriteria perancangan untuk waktu puncak kurang dari 1.5000 detik.

Untuk nilai puncak, tanggapan peralihan tegangan sistem AVR tipe arus searah untuk ketiga pengendali sudah memenuhi kriteria perancangan dimana nilai waktu puncak yang diinginkan kecil dari 1.5000 detik. Untuk pengendali Proporsional (P), tanggapan peralihan tegangan sistem AVR tipe arus searah mempuyai nilai puncak sebesar 0.8487 , untuk pengendali Proporsional Integral (PI) mempuyai nilai puncak sebesar 1.1352 dan untuk pengendali Proporsional Integral Diferensial (PID) mempuyai nilai puncak sebesar 1.1492.

Untuk nilai lewatan maksimum, tanggapan peralihan tegangan sistem AVR tipe arus searah untuk ketiga pengendali sudah memenuhi kriteria perancangan dimana nilai lewatan maksimum yang diinginkan kecil dari $20.0000 \%$. Untuk pengendali Proporsional $(\mathrm{P})$, tanggapan peralihan tegangan sistem AVR tipe arus searah mempuyai nilai lewatan maksimum sebesar $18.4772 \%$, untuk pengendali Proporsional Integral (PI) mempuyai nilai lewatan maksimum sebesar $13.5245 \%$ dan untuk pengendali Proporsional Integral Diferensial (PID) mempuyai nilai lewatan maksimum sebesar $14.9427 \%$.

Untuk waktu keadaan mantap, tanggapan peralihan tegangan sistem AVR tipe arus searah dengan pengendali Proporsional Integral Diferensial (PID) yang memenuhi kriteria perancangan dengan nilai waktu keadaan mantap sebesar 2.5562 detik sedangkan untuk tanggapan peralihan tegangan sistem AVR tipe arus searah 
dengan pengendali Proporsional $(\mathrm{P})$ dan pengendali Proporsional Integral (PI) tidak memenuhi kriteria perancangan dimana nilai waktu keadaan mantap untuk masing - masing pengendali sebesar 3.0109 detik dan 3.7537 detik.

\section{Kesimpulan}

Adapun kesimpulan dari penelitian ini adalah

1. Pengendali yang memenuhi kriteria rancangan untuk pengendalian tanggapan peralihan tegangan sistem AVR tipe arus searah adalah pengendali Proporsional Integral Diferensial (PID). Pengendali Proporsional Integral Diferensial (PID) ini dirancang dengan menggunakan metoda Ziegler-Nichols dengan pendekatan First Order Plus Dead Time (FOPDT) berdasarkan metoda fungsi alih.

2. Informasi hasil simulasi tanggapan peralihan sistem AVR tipe arus searah yang diperoleh dimana nilai kesalahan keadaan mantap sebesar 0.0000 , nilai waktu naik sebesar 0.6114 detik, nilai waktu puncak sebesar 1.4391 detik, nilai puncak sebesar 1.1492 detik, nilai lewatan maksimum sebesar $14.942 \%$ dan nilai waktu keadaan mantap sebesar 2.5562 detik.

3. Nilai parameter pengendali yang digunakan adalah k sebesar 13.2000, L sebesar 0.4283, T sebesar 1.0817, konstanta Proporsional $\left(\mathrm{K}_{\mathrm{p}}\right)$ sebesar 0.2296, konstanta waktu integral $\left(\mathrm{T}_{\mathrm{i}}\right)$ sebesar 0.8564 dan konstanta waktu diferensial $\left(\mathrm{T}_{\mathrm{d}}\right)$ sebesar 4.6667.

\section{Daftar Pustaka}

[1]. Sahib M, "A Novel Optimal PID Plus Second Order Derivative Controller for AVR System", Engineering Science and Technology, Vol. 18, pp 194 - 206, 2015.

[2]. Rajinikanth V \& Chandra S, " Design of Controller for Automatic Voltage Regulator Using Teaching Learning Based Optimization", Procedia Technology, Vol. 21, pp 295 - 302, 2015.

[3]. Al Gizi A, Mustafa M, Al - Geelani N, Alsaedi M, "Sugeno Fuzzy PID Tuning by Genetic Neural for AVR in Electrical Power Generation", Applied Soft Computing, Vol. 28, pp 226 - 236, 2015.

[4]. Laksono, H. D. \& Revan , M. "Perancangan dan Analisa Kendali Sistem Eksitasi Generator Tipe Arus Searah Dengan PIDTool Model Paralel", Teknika No. 03 Vol 21, Oktober, Seri Mekanika dan Kontrol, 2014.
[5]. Laksono, H. D. \& Revan , M. \& Rabiarahi, A. "Pemodelan dan Analisa Sistem Eksitasi Generator", Teknika No. 03 Vol 21, Oktober, Seri Mekanika dan Kontrol, 2014.

[6]. Aquila-Camacho N, Duarte-Mermoud, " Fractional Adaptive Control for Automatic Voltage Regulator", ISA Transactions, Vol. 52, pp 807 - 815, 2013.

[7]. Xue, D., Chen , Y. Q. \& Atherton , D. P. Linear Feedback Control : Analysis and Design With Matlab, Philadelphia : SIAM, 2007.

[8]. Kundur, P, Power System Stability and Control New Jersey: Prentice Hall, 1993 Control, New Jersey: Prentice Hall, 1993.

[9]. Saadat, H. Power System Analysis, New York: McGraw Hill, 1999.

\section{Biodata Penulis}

Heru Dibyo Laksono, lahir di Sawah Lunto, 7 Januari 1977, Menamatkan S1 di Jurusan Teknik Elektro Universitas Andalas (Unand) Padang tahun 2000 bidang Teknik Tenaga Listrik. Pendidikan S2 bidang Kendali dan Sistem diselesaikan di Institude Teknologi Bandung (ITB) tahun 2004. Masuk sebagai dosen Teknik Elektro Universitas Andalas sejak tahun 2005.

Novia Riska, Lahir di Bukittinggi, 10 November 1995. Terdaftar sebagai mahasiswa jurusan Teknik Elektro Fakultas Teknik Universitas Andalas pada tahun 2014 dengan bidang keahlian sistem kontrol.

Novizon, lahir di Padang, 8 November 1966, Menamatkan S1 di Jurusan Teknik Elektro Universitas Sriwijaya (Unsri) Palembang tahun 1991 bidang Teknik Tenaga Listrik. Meyelesaiakn pendidikan Magister di Universiti Teknologi Malaysia (UTM) tahun 2010 bidang Teknik Tegangan Tinggi dan melanjutkan pendidikan doktor di Universitas yang sama tamat pada tahun 2016 Masuk sebagai dosen Teknik Elektro Universitas Andalas sejak tahun 1997. 